NBER WORKING PAPER SERIES

\author{
POPULATION GROWTH, LABOR SUPPLY, \\ AND EMPLOYMENT IN \\ DEVELOPING COUNTRIES
}

\author{
David E. Bloom
}

Richard B. Freeman

\author{
Working Paper No. 1837 \\ NATIONAL BUREAU OF ECONOMIC RESEARCH \\ 1050 Massachusetts Avenue \\ Cambridge, MA 02138 \\ February 1986
}

We thank reviewers from the Committee on Population at the National Academy of Sciences for useful comments. We also thank Vijaya Ramachandran for excellent research assistance and for especially helpful discussions and suggestions. The research reported here is part of the NBER's research program in Labor Studies. Any opinions expressed are those of the authors and not those of the National Bureau of Economic Research. 
NBER Working Paper \#].837

February 1986

\title{
Population Growth, Labor Supply, and Fmployment in Developing Countries
}

\begin{abstract}
The economies of the less developed countries are about to face perhaps the greatest challenge in their histories: generating a sufficient number of jobs at reasonable wages to absorb their rapidly growing populations into productive employment. In terms of absolute magnitude, this challenge has no precedent in human history. In some respects, this challenge is also unprecedented in terms of its nature, given, on the one hand, the limited availability of natural resources in many countries and, on the other hand, the widespread availability of advanced technology.

This paper examines the nature and magnitude of the principal effects of population growth on labor supply and employment in the developing economies of the world. On the supply side of labor markets, we discuss key features of the interrelations between population growth and the labor force. These include the lags between population growth and labor force participation; the independent effects on labor supply of accelerated population growth due to changes in fertility, mortality, and migration; patterns and trends in labor force participation rates; and gender differences in labor supply behavior. On the demand side, we describe and analyze the nature of labor markets in developing economies and attempt to identify the key factors that condition their labor absorption capacity.
\end{abstract}

Descriptive statistics on the characteristics of developing country labor markets and on the relationships between population growth, labor supply, employment shifts, and growth of output per worker are presented and discussed.

The key result of our analysis is that, despite the unprecedented magnitude of population growth and the existence of imperfections in labor markets, developing economies tended to shift between 1960 and 1980 , from lowproductivity agriculture to the higher productivity service and industrial sectors and, albeit with some exceptions, to raise real income per capita.

With respect to their prospects for the remainder of this century, we also conclude that Malthusian disasters will not necessarily be the result of forecasted population growth, provided the developing economies can generate human and physical capital investments of comparable relative magnitudes to the past two decades. However, on the bas is of past history, the middleincome developing countries are likely to perform better in this respect than the low-income countries, some of whom may need considerable help if they are to absorb increased population while shifting labor to more productive sectors and raising output per worker.

David E. Bloom

Department of Economics

Harvard University

Cambridge, MA 02138
Richard B. Freeman

Department of Economics

Harvard University

Cambridge, MA 021.38 
Abstract

I. Introduction

II. Population Growth and Labor Supply

III. Labor Supply and Employment

IV. Population and Employment, 1960-1980

V. Country-Specific Experiences

VI. Conclusions and Speculations About the Future Notes

References

Tables

Appendix 
POPULATION GROWTH, LABOR SUPPLY, AND EMPLOYMENT

IN DEVELOPING COUNTRIES

\section{Introduction}

The population of today's less developed countries increased by roughly 1.2 billion people between 1960 and 1980. This increase is larger than the 1984 population of all of the more developed countries of the world combined. [1] It is also more than twice the 1984 population of Africa, and three times the 1984 population of Latin America. By the end of this century, all of the surviving children of this global baby-boom wili have reached working ages. In the first twenty years of the next century, this pattern will repeat itself, but with even larger numbers. 1.7 billion people are expected to be added to the populations of today's developing countries between 1980 and the year 2000 . This increase is roughly equal to the total population of the less developed world as recently as 1950. [2]

As these projections and comparisons make clear, the economies of the less developed countries are about to face perhaps the greatest challenge in their histories: generating a sufficient number of jobs at reasonable wages to absorb their rapidly growing populations into productive employment. In terms of absolute magnitude, this challenge has no precedent in human history. In some respects, this challenge is also unprecedented in terms of its nature, given, on the one hand, the limited availability of natural resources (and especially land) in many countries and, on the other hand, the widespread availability of advanced technology.

The purpose of this paper is to examine the nature and magnitude of the principal effects of population growth on labor supply and employment in the 
developing economies of the world. We do this mainly by analyzing the effect of population growth on the operation and evolution of developing country labor markets. On the supply side of the market, we discuss key features of the interrelations between population growth and the labor force. These include the lags between population growth and labor force participation; the independent effects on labor supply of accelerated population growth due to changes in fertility, mortality, and migration; patterns and trends in labor force participation rates; and gender differences in labor supply behavior. On the demand side of the market, we describe and analyze the nature of labor markets in developing economies and attempt to identify the key factors that condition their labor absorption capacity.

Although it is tempting to try, we do not provide a comprehensive empirical description of the structural labor supply and labor demand changes that result from rapid population growth. Cross-country experiences vary too widely and data on many key variables are too sketchy and unreliable. Moreover, our review of existing literature indicates that there is no standard pattern of labor market responses to population growth to which a large number of countries closely conform. We will, however, buttress our descriptive analysis with a discussion of a range of country-specific experiences.

In proceeding this way, we hope to clarify some of the labor market issues that are central to the ongoing debate between two groups of leading students of the relationship between population and development: the population pessimists and the population optimists. [3] On the one hand, the pessimists advance the view that rapid population growth hinders the growth of income per capita, thereby reducing rates of savings and investment, and resulting in mass underemployment, unemployment, and poverty. The optimists, on the other hand, 
stress the point that population growth can stimulate both technological change and the adoption of techniques that realize economies of scale, and therefore promote economic growth. Indeed, cross-country correlations between growth in income per head and the rate of population growth are typically quite weak [4] and there are a number of countries that have simultaneously experienced rapid growth of both their economies and populations. Until the 1930's, moreover, population tended to grow more rapidly in countries with more rapid productivity growth, most notably of course in the areas settled by European immigrants.

As we will try to make clear, these alternative views are overly simplistic. Population and labor force growth are not necessarily related strongly to labor absorption. Other factors, including labor market imperfections and technical considerations relating to the marginal productivity of labor in agriculture are also key conditioning variables.

In Section II we discuss the relationship between population growth and labor supply and analyze selected descriptive statistics. In Section III we discuss the nature of labor demand in models of developing country labor markets. Section IV analyses descriptive statistics on structural changes in employment in less developed economies and on the growth of employment relative to the growth of output per capita. It presents our chief optimistic finding: that despite the unprecedented population growth in developing countries in the 1960-80 period, the countries were generally able to "absorb" the new labor supply at increased productivity and with a shift towards more productive employment. Section $V$ presents a discussion of recent labor market experiences in a number of individual developing countries. Section VI outlines our conclusions and offers some speculations on the ability of developing economies to absorb the massive numbers of workers that will enter their labor markets in the next few decades. 


\section{Population Growth and Labor Supply}

\section{A. Conceptual Interrelations}

The purpose of this section is to identify and discuss the principal linkages between population growth and labor supply. In so doing, we will simply think of labor supply in terms of published labor force participation rates (i.e., the ratio of individuals who are either employed or unemployed but seeking work, to employed, unemployed, and economically inactive individuals). We will overlook issues relating to the number of hours people work, to measurement problems related to the determination of whether individuals are, or would like to be, "economically active," and to qualitative characteristics of members of the labor force such as their ability and motivation. Although these characteristics of a working population are obviously important determinants of an economy's productive capacity, the measurement issues they raise are simply beyond the scope of this paper. [5]

Generally speaking, the labor supply forthcoming from any population depends on the size of the population, broken down into different sex and age groups, and the participation rates for each of those groups. Whereas population size by age and sex is directly determined by population growth (and more specifically, by the history of fertility, mortality, and migration patterns), participation rates tend to be more economically and culturally determined. For example, labor force participation is nearly universal for prime-aged males in less-developed economies, whereas its incidence is considerably lower for younger and older men. Participation rates for these latter groups also exhibit considerable variability over time and across countries. In addition, although it is well known that published labor force 
participation rates for women are poor indicators of their economic activity levels (especially in countries in which women work predominantly in agriculture), these rates tend to vary widely across countries and over time and to be lower at each age than corresponding rates for men. Nevertheless, it is undoubtedly the case that labor force participation rates are themselves influenced by the same fertility, mortality, and migration patterns which determine population size. Thus, in discussing the effects of population growth on labor supply, we will want to distinguish between pure "accounting" effects and other effects which are fundamentally "behavioral" in nature.

There are three main points we would like to make about the interrelationship between population growth (and changes in population growth) and labor supply: (1) population growth will affect labor supply with a lag whose length depends on the reasons underlying the growth; in particular, an acceleration of population growth because of an increase in net in-migration or a decline in mortality will have a different impact on the labor force than an acceleration of population growth that results from an increase in fertility; (2) fertility and mortality levels are important determinants of labor supply, independently of their relation to each other; and (3) fertility increase and mortality decline are likely to have an immediate effect on labor supply through their "behavioral" effects on labor force participation rates. We will consider each of these points in turn.

(1) It is well known that population growth will tend to have a lagged effect on labor supply. For example, if population growth is the result of relatively high fertility or of an age distribution that is heavily concentrated in the childbearing years, the growth in any year will have its impact focused at age 0 of the age distribution. Thus, it will take at least ten to fifteen 
years before the effects of a particular year's population growth even begin to be felt in the labor force. It will probably be more like 20 to 25 years before the net additions to the population begin to have a substantial impact on its labor force. [6]

On the other hand, if population growth is mainly the result of substantial in-migration, its principal effect on labor supply will not be lagged since migration propensities tend to be relatively low before the teenage years. Although in-migration is a relatively small contributor to population growth in most developing countries, this point also applies to regions within a country. In other words, population growth resulting from an excess of births over deaths in rural portions of an economy may create pressures for migration to urban areas. To the extent that the migrants tend to be of working age, population growth in the urban areas will have an immediate -- as opposed to a lagged -effect on labor force growth. [7]

(2) Although changes in levels of fertility and mortality will both affect population growth rates, they will do so in ways that tend to have different labor force implications. For example, an acceleration of population growth because of an increase in fertility will result in a more steeply sloped age distribution and a higher dependency burden, both immediately and when the population achieves a stable form. In contrast, an acceleration of population growth due to a mortality decline may steepen the age distribution somewhat, and increase the dependency burden of the population, but not by as much as a fertility increase. This difference is due to the fact that the effects of mortality decline are not concentrated at one point on the age distribution but rather, spread out across the age distribution. In fact, mortality declines will affect the age distribution differently at different initial levels of 
mortality. For example, it is well known that mortality reductions in high-mortality populations are enjoyed mainly by infants and young children, whereas mortality reductions in middle mortality populations are more evenly spread throughout the age distribution. (In low mortality populations, mortality declines are largely concentrated at the oldest ages, where labor force participation rates are quite low.) Thus, mortality declines in highmortality populations will be analogous to fertility increases and therefore have effects on labor supply that have long lags. In contrast, mortality declines in middle-mortality populations will be more immediately felt throughout the age distribution.

Because changes in mortality and fertility tend to differentially affect an age distribution, even holding constant the rate of natural increase in a stable population, fertility and mortality levels are potentially important determinants of the proportion of a population in the working ages. To illustrate this point, consider the example of the two west model stable populations presented in MCNicoll (1984a, p. 187). The first population has a birth rate of 4.5 percent and a death rate of 2.0 percent, while the second population has a birth rate of 3.0 percent and a death rate of 0.5 percent. Thus, both populations have identical rates of increase. However, they do not have identical age distributions. In the first population, 54 percent of the population falls between the ages 15 and 64 . In the second population, 57 percent of the population is of working age. Although this difference in the age distributions is not particularly large, it does illustrate the point that fertility and mortality levels have an effect on the age distribution -- and therefore on the labor force -- that is independent of their crude difference.

(3) The final point about the effect of population growth on labor supply 
relates to the behavioral relationships between fertility and mortality levels and changes and labor force participation rates. To begin with, it must be recognized that childrearing and labor force participation are both timeintensive activities in developed and developing countries alike. It is, however, difficult to generalize about the extent to which women can engage in both simultaneously. For example, in some high fertility populations, women are constrained either from working at all or from working away from the home. But in other high fertility populations women are able to spend a great deal of time working outside the home by having older children take care of their young children. Despite the difficulty of generalizing, the possibility of combining children and work is greater in rural areas of developing countries than in urban areas since the workplace and the home are not separated by as much time and distance. In addition, women have relatively more freedom to work, at least for a greater portion of their lives, in low fertility populations. Thus, a decline in fertility may have an immediate impact on the size of the labor force because of its effect on the participation rates of women. Empirical evidence on this point is mixed, however, with participation rates of 30-45 year old women increasing after fertility declines in some countries, and decreasing in others. As noted above, this suggests that labor force participation rates of women, which can be an important component of overall participation rates, are not just economically determined, but also culturally determined, in many developing economies. Of course, this conclusion is weakened to the extent that the types of jobs women do are also culturally and economically determined, since some economic activities are measured better than others (i.e., "disguised employment" may be an important issue). [8] Mortality changes may also have an effect on the labor force. In this 
case, however, the effect does not operate entirely through the effect of mortality decline on age-specific participation rates. Rather, the effect also operates through the positive effect of declining morbidity on the quality and productivity of the labor force. Of course, to the extent that a decline in mortality is perceived by individuals as extending their worklife horizons, it may also provide greater incentives for undertaking human capital investments. Whereas such investments will tend to contribute to the overall quality of the labor force, it will also tend to delay the entry of individuals into the labor force and therefore reduce aggregate participation rates. Indeed, one of the few patterns in labor force participation rates that has been observed with some degree of regularity in different developing economies is the declining rate of labor force participation for both men and women at the younger ages, a trend that is highly correlated with the expansion of developing countries' education systems.

\section{B. Empirical Patterns}

In this section we present and discuss evidence on the linkages between population growth and the size and the structure of the labor force in developing countries. Most of the statistics we analyze are drawn from various publications of the World Bank, although some of those statistics were originally produced by the UN or the ILO. Countries will be grouped in two conventional ways for purposes of our analysis: by income group and geographic location. The income classification is based on levels of GNP per capita for most countries, with other characteristics thought to be correlated with income group used to classify countries for which per capita GNP data are either unreliable or unavailable. The figures for low-income developing economies are 
based on data for 34 countries whose 1982 per capita GNP was less than 410 U.S. dollars (average income per capita for these countries is 250 U.S. dollars). The figures for lower middle-income economies are based on data for 38 countries whose 1982 per capita GNP exceeded 410 U.S. dollars but was less than 1650 U.S. dollars (average per capita income for these countries is 840 dollars). The figures for the upper middle-income developing economies are based on data for 22 developing economies with GNP per capita in excess of 1650 U.S. dollars (average equais 2490 doilars). Finaily, the figures for the industrial market economies are based on data for 19 countries that had an average GNP per capita of 11070 dollars.

The geographic grouping of developing economies also follows the standard World Bank classification. Thus, countries are grouped into the following regions: (1) Sub-Sahara Africa, 34 countries; (2) Middle East and North Africa, 11 countries; (3) East Asia and Pacific, 14 countries; (4) South Asia, 8 countries; (5) Latin America and Caribbean, 22 countries; and (6) South Europe, 5 countries. All of the countries represented in our tables are listed individually by income group and geographic region in Tables A.1 and A.2 of the Appendix. All of the population, labor force, and output statistics reported represent weighted averages of the individual country statistics, with 1960 , 1970, or 1980 population sizes used to construct the weights. For the low-income developing countries, statistics are reported both separately and together for China, India, and other low-income countries.

Table 1 presents growth rates of population and labor force by countries grouped according to income. The statistics in this table reveal several interesting patterns. First, with the exception of China after 1970, population growth rates for the low-income and lower middle-income developing countries 
have been extremely high since 1960 (i.e., implied doubling times are less than 30 years). Population growth rates in the upper middle-income developing countries have also been quite high although they are showing some evidence of moderating. In contrast, the decline in the growth rate for China is substantial. Indeed, this decline is larger in proportionate terms (e.g., from an implied doubling time of 30 years in 1960-70 to 50 years in 1970-82) than for the industrial market economies (which had an implied doubling time of 100 years during the 1970-82 period).

Second, declining population growth rates in the 1970's have not yet shown up in the form of declining labor force growth rates for either China, the upper middle-income developing economies, or the industrial market economies. This pattern illustrates the point made in the preceding subsection about the existence of a time lag between population growth and labor force growth.

The third noteworthy pattern in Table 1 is that during the 1960-82 period, none of the groups of developing countries (with the single exception of China in the 1970's) experienced labor force growth in excess of population growth. If there had been either no technological progress in this period or no increases in capital per worker, these economies' productive capacities per capita would have declined between 1960 and 1982 . Nonetheless, the difference between population and labor force growth rates decreased for the developing economies between the 1960's and the 1970's. This decrease reflects the age distribution effects of population growth prior to 1960 and suggests that the secular deterioration of developing economies' ratios of labor force to total population is slowing. In China, this decline was actually reversed as labor force growth exceeded population growth during the 1970's.

Fourth, one pattern not revealed in Table 1 but worthy of note relates to 
the considerable variability of population and labor force growth rates between countries within the same income group. For example, among the low-income economies, Kenya and Mozambique had population growth rates of 4.0 and 4.3 percent between 1970 and 1982 while Sri Lanka and Haiti had growth rates of 1.7 percent. As another example, among the upper middle-income economies, Syria, Venezuela, and Iraq had population growth rates of about 3.6 percent from 1970 to 1982 , roughly nine times the rate of 0.4 percent in Uruguay and more than twice the rates in Argentina, Chile, and North Korea.

In Table 2 we present male and female labor force participation rates for a somewhat abridged income grouping of economies. One striking feature of these statistics is that the labor force participation rates of men in industrial market economies exceeded the rates for men in the two groups of developing economies in both 1960 and 1980. This differential results from the relatively older age distributions of the industrial market economies, a consequence of their lower rates of population growth. This pattern is especially interesting given that labor force participation rates for men tend to fall at the young and old ages as development proceeds (see Durand, 1975). In this case the demography of the age structure dominates the behavioral factors in determining aggregate labor force participation.

A second apparent regularity in Table 2 is that the labor force participation rates for males in the middle-income developing countries are lower than in the low-income countries. In addition, participation rates in both groups of countries have declined over time. These findings seem to reflect the facts that (1) population growth was substantial in both groups of developing economies in the 1950's and 1960's (as they began their demographic transitions), thereby tending to raise the youth share of their populations, and 
(2) population growth was relatively greater in the middle-income countries than in the low-income countries in the 1950's and 1960's, resulting in a greater increase in the youth proportions of their populations (and consequently a greater decline in their male labor force participation rates).

Turning now to the labor force participation rates for females, we observe a slight decline from 1960 to 1980 for the low-income developing countries, most likely due to the effect of population growth on the age distribution. On the other hand, we observe a stable pattern in the middle-income developing countries, although the participation rates are substantially below those of the low-income developing countries. Whether this difference is a consequence of the notoriously poor data on female labor force participation in developing countries and problems of definition in countries with large agricultural sectors, or whether it is indicative of a tendency for women to withdraw from the labor force as development proceeds, is unclear. It is also unclear whether this pattern is due to some omitted factors that affect the labor force participation of women and that are correlated with income group.

To get some idea of the extent to which the striking differences in the labor force participation rates of women in low and middle-income developing countries are due to an omitted variable problem, Table 3 reports participation rates in 1960 and 1980 broken down by geographic region. As this table makes clear, there is considerable variation in female participation rates across regions, although those rates are quite stable within regions but over time. In 1980, for example, participation rates for women ranged from 5.6 percent in the Middle East and North African countries to 33.5 percent for East Asian and Pacific countries (which is even slightly greater than the average rate for the industrial market economies). This pattern suggests that the dramatically 
different female labor force participation rates across income groups reported in Table 2 may be due to geographic participation differences that are correlated with income group or culture, as discussed earlier. Indeed, examination of the country breakdown (by income group and geographic region) in Appendix Table A.1 seems to confirm this supposition since none of the Middle East and North African countries and only one of the Latin American and Caribbean countries -- the two geographic groups with the lowest participation rates -- fall into the low-income developing category. Nonetheless, this conclusion is offered tentatively since the data on female labor force participation rates in these countries are thought to be especially poor.

Table 3 is also interesting with regard to the participation patterns for men. In particular, the participation rates are declining over time for all regions except East Asia and the Pacific. In addition, and in contrast to the pattern for women, male labor force participation rates exhibit relatively small differences across the developing countries.

As a basis for comparison, Table 3 also presents labor force participation rates for males and females in 1960 and 1980 in selected developed economies. Since these participation rates are computed relative to the population aged 15 (or 16) and over, they are not comparable in terms of their levels to the rates for the developing countries. However, the rates for men do show about the same degree of variation across countries and a similar tendency to decline over time. In the case of the developed countries the declines are largely due to increased educational attainment resulting in delayed entry into the labor force and to a decline in the age of retirement. (For some countries the declines are also partly the result of post-World War II baby-booms and their tendency to youthen the labor force.) To the extent that these patterns in the developed 
countries may be taken to foreshadow trends in the developing countries, we see that development carries with it forces that ease the burden on labor markets to adjust to rapid population growth.

In contrast to the rates for men, the participation rates for women in the developed economies show mixed trends over time. For example, participation rates climbed substantially between 1960 and 1980 in the U.S., Canada, Australia, the United Kingdom, and Sweden. During these same years, however, the rates increased little or declined in Japan, France, Germany, and Italy. This pattern for the industrial economies tends to confirm the point made in the preceding subsection about female participation rates tending to be much more culture-specific than the rates for men. It also adds a good deal of uncertainty to any attempts one might make to project female labor force participation rates for the developing economies.

Finally, turning back to demographic issues, consider the figures in Table 4, which present the percent of the population aged 15-64 (an approximate measure of the working ages) by income group. The statistics in this table show a large increase for China, reflecting its declining population growth rate. The estimates also show that developing countries have smaller proportions of their populations at the working ages than the industrial market economies, a reflection of their relatively high population growth rates which tend to increase the share of youth in their populations. The fact that the dependency burden (i.e., the inverse of the proportions shown in Table 4 ) in the developing countries is so high is, of course, a hindrance to development in two main ways. First, the high dependency burden indicates that these economies must sustain themselves on the income that can be generated by a relatively small proportion of their populations. Second, because most of the dependency 
burden in these rapidly growing populations is associated with the young, there is a relatively great need to invest social savings in welfare capital such as schools and hospitals for persons out of the workforce, as opposed to physical capital for persons in the workforce. 


\section{Labor Supply and Employment}

Modeling the relationship between population growth and employment is not a problem that is uniquely of interest in the developing country context. Following World War II, a number of industrialized countries, including the U.S., Canada, and Australia, experienced baby booms in which population growth was substantial. As the baby-boom generations in those countries began to reach labor force age, a theoretical and empirical literature on the labor market effects of large cohort size was spawned. The basic premise of that literature is quite simple: large cohort size suggests an outward shift of labor supply that has adverse implications for the labor market experience of the large cohorts relative to the experience of smaller cohorts. Moreover, there are two key dimensions along which these adverse implications may be observed: wages and employment (or unemployment).

One of the most interesting empirical findings of the baby-boom literature relates to the considerable diversity that appears to exist across countries in the nature of their adjustment to large-sized cohorts. For example, some countries (including the U.S.) appear to have adjusted to the baby boom mainly through a lowering of relative wages whereas the adjustment in other countries (including Canada) has primarily taken the form of diminished employment opportunities for members of the baby-boom cohorts. Perhaps the main lesson to learn from this diversity of experience is that labor market responses to population growth are not necessarily dictated by a simple supply-demand model which is common across countries. Rather, different countries may have differently-sloped labor supply and labor demand curves, different industrial mixes, and different labor market institutions and policies (such as minimum 
wages, government incentives to join the military or to stay in school, etc.), which result in different responses. Empirical work does seem to bear out, however, the theoretical notion that either wages or employment opportunities (or both) suffer as a result of an outward shift of labor supply that results from past population growth. [9]

These lessons about the labor market responses of industrial economies to population growth are also applicable to the experience of developing economies. Iñdeed, institutional factors and the siope of labor demand curves are crucial determinants of the capacity of developing economies to absorb growing populations into productive employment. In addition, as in the case of the developed economies, there seems to be considerable variation in the less developed economies with regard to the nature and operation of their labor markets, making it difficult to reach any general conclusions about the effects of rapid population growth on employment in developing countries. [10] However, several economic models of this relationship do shed light on the key variables that determine whether labor markets have more or less "absorptive"

To begin with, a standard one-sector neoclassical model of the labor market suggests that the degree to which population growth will be absorbed into employment will depend on the slope of the aggregate labor demand curve (e.g., if labor demand is perfectly inelastic an increase in labor supply will not be absorbed as increased employment; in addition, employed individuals will take wage cuts, unless there is a minimum wage, in which case there may be substantial involuntary unemployment). However, the theoretical literature on developing country labor markets does not focus on the slope of labor demand curves. Instead, the literature is largely oriented toward analyzing a feature of developing country labor markets which is thought to be critical to their 
operation: their dual nature. The dual sectors of a developing country labor market have been referred to by a variety of names. One sector is usually referred to as agricultural, rural, non-commercial, peasant, traditional, or backward; the other sector is usually referred to as capitalistic, nonagricultural, commercial, formal, modern, or urban. More recently, distinctions have been made between a formal and informal sector within the urban economy, creating a trichotomy: agricultural, informal urban, and formal urban (of which more will be said later). While there is considerable debate over the extent of mobility among the sectors, and the causes and meaning of potentially large income differences between sectors, their economic differences are important in any assessment of how the labor market will "absorb" population increases. Without losing ourselves in the semantics of the issue, we merely note that the key distinguishing feature of the sectors is the nature of their dominant production units. In the traditional agricultural and urban informal sectors, the production unit (e.g., a household) is characterized by self-employment and small-scale enterprise employment (exclusive of plantations). On the other hand, the chief characteristic of the production unit in the modern sector is that it is based on labor hired on a contractual basis. [11]

The earliest of the popular two-sector models is due to Arthur Lewis (1954, 1958). According to the Lewis model, the main characteristic of the traditional sector labor market is the presence of surplus (or excess, or redundant) labor. In one extreme version of this model, the marginal product of labor (i.e., the derivative of output with respect to the number of workers) in the traditional sector is zero. In other words, all members of a household who are able to work do so and they share the output with the entire household. Moreover, it is 
assumed that each production unit attains the maximal level of output possible from its non-labor resources, given its production technology. If the number of working members of a household increases, each member either works fewer hours (Sen, 1968) or expends less effort for the same number of hours (Leibenstein, 1978). This is the sense in which the marginal product of additional laborers is zero. In a less extreme version of this model, the marginal product of labor is viewed as being less than the average product (which is the wage received by the household's workers). It makes littie difference to the quaitative implications of Lewis' model which assumption is correct.

The capitalist sector in the Lewis model closely resembles a neoclassical labor market. Employers have garden-variety downward-sloping labor demand curves and they hire labor to the point at which the marginal product of labor equals the market wage. This wage will be determined by the nature of alternative job opportunities available to modern sector workers. Thus, in a closed and frictionless economy, the market wage in the modern sector will equal the average product in the agricultural sector. However, because of the transactions costs associated with migration to the modern sector, most models of developing economy labor markets view modern sector wages as being greater than the average product of labor. This feature of the theoretical models is consistent with empirical evidence that demonstrates the existence of a positive wage differential between the industrial and agricultural sector in most though not all developing countries (see Table 5) as well as uniformly higher output per worker in industry and services relative to agriculture (see Table 11 ). Within the context of this two-sector model, one can easily identify the linkages between population growth and labor absorption. In particular, at early stages of development, the supply of labor to the modern sector is 
horizontal at a relatively low wage because of the existence of surplus labor in the agricultural sector. Enterprises will thus earn relatively high profits, a substantial fraction of which they are assumed to reinvest. Consequently, capital formation will be relatively great in the labor surplus economy and will lead to further outward expansion of labor demand, thereby resulting in the dynamic expansion of employment. Thus, a large population in the agricultural sector promotes the growth of industry by making available a large supply of low-wage labor. [12]

In terms of its dynamic properties, the economy described by this simple model does not continually experience rapid economic growth. Eventually, the modern sector draws enough labor out of the traditional sector so that the marginal product of labor in the agricultural sector equals its average product. Beyond this point, as capital formation leads to further economic expansion, alternative opportunities will improve for both potential and actual modern sector workers and urban wages will rise. This will, of course, tend to moderate the further growth of employment -- although it will not curtail it completely. Moreover, during this second phase of development (i.e., beyond the point at which the aggregate labor supply curve begins to slope upward) the importance of distinguishing between the two sectors of the economy is lost because both sectors behave neoclassically. Naturally, reaching this turning point does not signify that an economy is no longer developing. More interesting to analyze, because it seems to characterize the experience of a greater number of developing countries, is the effect of rapid population growth on the labor market before an economy reaches its "turning point." Here, the basic idea is that population growth leads to a fall in average product in the agricultural sector, which may lead to a fall in the industrial sector wage, 
although the more important effect of population growth is that it extends the horizontal portion of the labor supply curve faced by the industrial sector employers. Thus, by expanding the reservoir from which modern sector firms are able to hire labor, and perhaps making that labor even cheaper, population growth postpones the point at which wages increase, and leads to a decline in living standards in both the agricultural and industrial sectors along the way. In addition, as the discussion makes clear, just focusing on the absorption problem associated with population growth may be a bit misguided since, in both dual and neoclassical economies, an increase in population may be substantially or even completely absorbed into the employed labor force at the cost of reduced wages and living standards.

Although the main implication of this basic model is that population growth slows the rate at which surplus labor decreases and postpones the elimination of dualism and a rise in living standards, this model can be (and has been) complicated in a variety of ways that have significant implications for the relationship between population growth and employment. We will not, in the remainder of this section, attempt a comprehensive review of the many twists on the Lewis model, but we will discuss the main variations. [13]

First, one of the most widely observed facts about the operation of developing country labor markets is that the difference between modern sector and agricultural sector wages exceeds the amount that would cover transactions costs associated with movement from one sector to the other. In some cases, the excess is substantial (see Table 5). A common explanation of these wide differentials is the existence of labor market imperfections in the modern sector. For example, it is often argued that modern sector wages are set institutionally by the government at artificially high levels, perhaps because 
of trade union pressure or politics associated with other interest groups. To the extent that wages are maintained at artificially high levels, employment will be lower than it would otherwise have been, and capital formation will proceed at a slower rate. [14]

Table 6 presents some readily available information on one such imperfection -- the minimum wage. At the present time, minimum wages, which were introduced into most developed countries much later in their economic histories, are found in virtually all developing countries, although the level and enforcement of the minimum varies substantially across them. The figures in the table show that minimum wages are typically set at 30-50 percent of manufacturing wages, which are comparable to the levels of minimum wages in developed countries relative to their manufacturing wages. It is likely that the minimum wages are solely enforced in the larger modern sector enterprises and thus impact not so much levels of total employment as employment in those enterprises.

of equal or greater importance than minimum wages in creating dualistic labor market structures are the government pay policies in many developing countries. As Table 7 shows, public sector employment constitutes a relatively large proportion of nonagricultural employment in many developing countries and, ipso facto, an even larger proportion of formal modern sector employment. The proportions far exceed those in currently developed countries at a similar stage in their economic histories, giving government pay policy a potentially important role in creating and maintaining dualistic markets. Finally, as Table 8 shows, government pay in developing countries has tended to be much larger than per capita income, with the differences greatest in the poorest countries. Until the 1980's, the "overpaid civil servant" was often cited as a problem in 
African countries.

While one might expect the effectiveness of policies in altering modern sector wages relative to those elsewhere to be extensively studied, with firm research conclusions, in fact there are only scattered studies for developing countries, and no clear consensus of either the direction or effectiveness of the policies. According to one leading scholar, "the experiences of the various countries has called attention to the importance of the role of government in creating wage distortions." [15] In a similar vein, another analyst contends that "the root of the wage problem lies in one fact: the export giants and local monopolies are willing ... to pay high wages." [16] By contrast, another scholar argues that "the high wage policy that allegedly characterizes LOC's ... is a misrepresentation." [17] With respect to unionism, while many attribute high wages in Africa to union influence, some studies have found lower wages in unionized sectors, suggesting that organized sectors are more amenable to incomes policies. [18] In his summary of the debate in 1977, Webb cited studies showing both "the role of active or permissive government wage and unionization policies" in raising wages and the converse, with lack of enforcement of policies (such as those regulating minimum wages) making nominal policy-initiated wage increases ineffective. [19] In her analysis, Krueger noted "how little is known" about labor market distortions due to policies. [20]

A second widely observed fact about the operation of developing country labor markets is that rates of rural to urban migration have tended to exceed the absorptive capacity of the modern sector, leading to growth of the "informal sector." This fact is consistent with our earlier point about the differential between industrial and agricultural sector wages, given that migration is generated by a Harris-Todaro type of migration model (or some variant thereof). 
According to that genre of models, migration flows do not equalize observed wages across sectors; rather, they equalize expected wages. Thus, given the existence of rural-urban wage differences in excess of the amount due to transactions costs, the migration flow to the modern sector will surpass its ability to absorb additional labor (i.e., because equilibrium is reached when the probability of securing employment in the modern sector times the modern sector wage is equal to the actual wage in the rural sector plus mobility costs).

If rural-urban migration is generated according to a Harris-Todaro type of model, migration flows will tend to be greater the higher are institutionallydetermined wages in the modern sector. However, since industry is unable to absorb labor as fast as it arrives, one would expect to observe substantial urban unemployment, which turns out not to be the case. Instead, we have observed the rise of a tertiary sector in urban areas -- an informal sector in which individuals queued up for high-wage industrial employment work as handicraftsmen, artisans, and suppliers of a variety of personal services. To the extent that this group of workers is underutilized, they may be viewed as a group of "disguised unemployed" workers in the urban sector.

Several additional comments about the urban informal sector also seem in order. First, it is widely hypothesized that the informal sector arises because of the way in which labor markets operate in developing countries, with institutionally-fixed wages in excess of market wages. This feature of urban labor markets suggests that both measured unemployment and the growth rate of the urban labor force are poor measures of the absorption power of an economy. In other words, informal sector employees work in a labor market that is perhaps more closely akin to the traditional sector than to the modern sector. However, 
two features of the informal sector do suggest that it is a positive force in the development process. First, to the extent that one factor limiting the absorption of workers into industry is their lack of understanding of the culture of the urban sector (e.g., requisite work habits and other skills), the presence of a traditional-like sector in an urban area can serve as a massive training and acculturation program that partially eases hiring constraints faced by employers. Second, largely because of the high cost of housing in urban areas, the distance between home and work, and the fragmentation of family units that often accompanies rural-urban migration, urban-dwellers tend to have lower fertility than rural-dwellers (although there seems to be no definitive evidence on this often-asserted point). Thus, growth of the informal sector may help to curb population growth. The main upshot of all this, then, is that population growth seems to be transforming the structure of developing country labor markets from dual-sector to tri-sector in nature with two main implications: (1) that new measures of labor absorption are needed and (2) that a tri-sector labor market may be an efficient mechanism for helping to curtail population growth and for channeling surplus agricultural labor into industry, and therefore promoting development.

The final major wrinkle on the basic Lewis model relates to the dynamics of technological and institutional change in developing economies. In the original version of the Lewis model, production functions were assumed to be stable over time. However, it has been argued that population growth stimulates technological progress and makes possible the realization of economies of scale that provide incentives for the adoption of more efficient techniques and institutional arrangements (see Binswanger, 1979; Boserup, 1981; and Hayami and Ruttan, 1985). It has also been argued, although without supporting evidence, 
that population growth leads to the birth of more "geniuses," some of whom may contribute to technological progress and others of whom may determine how to reorganize production in a way that effectively taps the productive capacity of excess rural labor (see Kuznets, 1965; and Simon, 1981). Taken together, these notions suggest that population growth promotes development by moving outward an economy's production possibility frontier. Although it is of critical importance to know whether the outward shift is greater than or less than some appropriate measure of the increase in population, these ideas cannot be refuted at a theoretical level. However, in an excellent review of existing studies of these issues, McNicoll (1984a) concludes that the evidence so far is mixed. [21] A second technology-related issue involves recent attempts to identify a key difference between the past experience of today's developed economies and the prospective experience of today's developing economies. Briefly, the argument is that countries trying to develop today are doing so in the context of surplus labor and readily-transferable capital-intensive technologies. In contrast, the development experience of today's industrial market economies was generally characterized by labor shortages and less advanced technologies. In other words, while industrial market economies adjusted to their situation by developing labor-saving technology, today's developing economies would probably be best off developing labor-intensive methods of production. However, the presence of already-developed transferable technologies from the industrial economies, with scarce capital to back it up, substantially eliminates those incentives. Thus, it has been argued that patterns of technological development and utilization today are tending to reduce the absorptive capacity of developing economies since industrialization is taking place without labor absorption. [22] 
To sum up the main point of this section, at a theoretical level, population and labor force growth are not necessarily strongly related to labor absorption. A variety of factors condition the absorptive ability of an economy, allowing some analysts to argue that economies can readily absorb a large increase in the labor force (under specified conditions) and others to argue the converse (also under specified conditions). The issue is an empirical one, on which observed historical experience can contribute significantly to an assessment of the optimistic and pessimistic views of the efects of rapid population growth. 
IV. Population and Employment, 1960-1980

As the preceding section makes clear, a central indicator of the pace at which a developing economy is absorbing labor is the rate at which the sectoral balance of the economy is shifted from agricultural to nonagricultural employment. In this section, we present and discuss a series of statistics on these shifts. We will use World Bank data to examine differentials across both income groups and geographic regions. The three sectors on which we will focus our attention are the agricultural, industrial, and service sectors. The agricultural sector encompasses forestry, hunting, and fishing, in addition to agriculture. [23] The industrial sector is comprised of manufacturing, mining, construction, and utilities. Services are defined as a residual category of economic activity (i.e., not agriculture or industry, as defined above). Although we focus our attention mainly on the expansion of the industrial and service sectors, we do not mean to suggest that agricultural development is of little consequence. Indeed, increases in productivity in the agricultural sector, which we will also discuss, usually precede and are the primary cause of sectoral shifts in employment. [24]

The key result of our analysis is that, in the 1960-80 period, despite the unprecedented magnitude of population growth and the existence of imperfections in labor markets, developing countries tended to shift from low-productivity agriculture to the higher-productivity service sector and to a slightly lesser extent to the high-productivity industrial sector, and to raise income per head, although with some exceptions (e.g., some African countries). We do not address the question of whether these changes could have been more extensive in some counterfactual world with slower growth of population and labor force. 
Table 9 reports the distribution of the labor force across economic sectors in 1960 and 1980 , by country income categories. A number of patterns are revealed by this table. First is the well-known fact that the fraction of the labor force engaged in agricultural production is inversely related to the stage of development. In addition, there was a decrease in the share of the labor force in agriculture between 1960 and 1980 for al1 income groups in Table 9. However, with the exception of the upper middle-income developing economies, agriculture has been and remains the largest utilizer of labor in the developing economies. Even in the upper middle-income countries, the proportion of the labor force in agricuture was five times that in the industrial market economies in $1980 .[25]$

Second, Table 9 reveals that the relative decline of agriculture coincided mainly with growth in the share of the labor force in the service sector, which tended to be larger in size than the industrial sector in both 1960 and 1980 . It is interesting to note, however, that an important exception to the pattern of services comprising a larger share of the labor force than industry is China (in 1980), in which this pattern is reversed, and substantially so. With regard to country-specific differences, the statistics for India are also interesting insofar as they show a relatively small decline between 1960 and 1980 in the proportion of the labor force in agriculture.

Table 10 is similar to Table 9 except that the sectoral labor force shares are reported for developing countries grouped by their geographic region (and not by their income). This table indicates the existence of large differences across regions in the sectoral share distributions. For example, the agricultural sector is substantially more dominant in South Asia and Sub-Saharan Africa in both 1960 and 1980 than it is in the Middle East and North Africa and 
in Latin America and the Caribbean. Table 10 also indicates that the decline of the labor force share in agriculture between 1960 and 1980 was associated with an increase in the labor force share in both industry and services -- in all regions. However, there were some differentials in the extent of decline in agriculture and the relative expansion of industry and services. For example, the biggest decline in agriculture was in the South European countries, while the smallest decline was in the South Asian countries. Of the regions experiencing the largest declines in agriculture, services tended to grow the most, although not necessarily in proportionate terms. In this regard, the Middle East and North Africa stand out, insofar as their moderate decline in agriculture was associated with a growth rate in industry that exceeded the growth rate in services.

Taken together, Tables 9 and 10 indicate the existence of differences in both regions and income groups in the sectoral distribution of the labor force. These tables also provide evidence of changes over time, only some of which have been uniform across income groups and geographic regions.

The shifts in the labor force distribution shown in Tables 9 and 10 have, it is important to note, contributed to increased income per capita in developing countries. To see this we have made a two-part calculation. First, we have estimated relative labor productivity in each sector; second, we have evaluated the impact of changes in labor force allocation across sectors to the growth of economy-wide productivity. Table 11 reports the results of our first calculation. It shows the ratio of gross domestic product per worker in agriculture, industry, and services to the economy-wide gross domestic product per worker. Figures greater than 1.0 indicate that a sector has above-average productivity. Figures below 1.0 indicate the reverse. In all income groups of 
economies, agriculture has below-average productivity. In all but the industrial market economies, industry has markedly higher average productivity, as does services. There is, moreover, a general tendency for the industry-toall-economy differential to fall as agriculture's share of the labor force drops.

Table 12 provides estimates of the contribution of the labor force shifts shown in Table 9 to the growth of GDP per worker from 1960 to 1980 . It uses 1960 relative GDP per worker and 1980 relative GDP per worker as "productivity weights" to evaluate the shift. The results show that in the developing countries (with the exception of India), changes in the sectoral distribution of the labor force have contributed significantly to the growth of overall labor productivity: a 21-25 percent increase in middle-income developing countries and a 14-15 percent increase in low-income countries exclusive of China and India. With productivity growth over the period of nearly 150 percent in middle-income developing countries and about 100 percent in low-income countries, the observed ability of the labor markets to shift labor to the relatively more productive sectors despite rapid population growth contributed from one-tenth to one-fifth of observed overall productivity growth.

The next issue that needs to be addressed goes beyond establishing the existence of patterns or changes in the sectoral distribution of the labor force. Rather, it involves assessing whether or not developing countries have been expanding their productive capacities within sectors. In other words, have the sectoral shifts affected output per worker, within or between sectors, as in the simple Lewis model?

Table 13 provides us with a preliminary answer to this question. This table presents statistics by country income groups, on the growth of GDP and the 
labor force between 1960 and 1980, broken down by economic sector. Presumably, if economic development were not taking place, one would expect this table to reveal GDP growth falling short of labor force growth. One would also expect to see little evidence of growth in the agricultural sector's share of GDP due to the presence of surplus labor. Alternatively, agricultural productivity (i.e., the difference between the growth of GDP from agriculture and the growth of the agricultural labor force) would tend to be stable or decline over time. Finally, one would expect to observe little growth in the share of GDP coming from industry because of the slow growth of capital, and little growth in the share of GDP coming from services because of the slow emergence of an informal sector.

Table 13 is highly illuminating on all of these points. Over the 1960-80 period, GDP growth actually exceeded labor force growth in all three economic sectors and for all income groups of economies. Thus, GDP per member of the labor force, a crude measure of productivity, increased over time. However, the magnitude of the increase was relatively small in the agricultural sector. For example, in low-income developing countries, GDP associated with agricultural output grew 56 percent between 1960 and 1980, while the agricultural labor force grew by about 35 percent. In other words, output per labor force member grew by roughly one-fifth over this twenty-year period. In comparison to this figure, output per labor force member grew four times as much in the industrial and service sectors of low-income developing economies. For middle-income developing economies, agricultural output per agricultural labor force member grew by about 75 percent between 1960 and 1980. In comparison, this measure of productivity grew by approximately 140 percent in industry and 60 percent in services. This last figure is particularly interesting since it indicates that productivity 
growth in the service sector was less than in agriculture in the middle-income developing economies. However, this pattern is more an indication that agricultural productivity growth was large, than an indication that service productivity growth was small. For example, the productivity growth figures for agriculture and services in the middle-income developing countries are extremely close to those for the industrial market economies. Perhaps the pattern of agricultural productivity growth in middle-income developing countries signals that population growth has either stimulated technological change or has reached the point at which these countries have sufficient incentives to adopt more efficient production techniques or economic institutions. It also seems worth noting that overall GDP growth per labor force member grew more in the middle-income developing countries between 1960 and 1980 than in the low-income developing economies or the industrial market economies, where roughly equal growth rates were attained.

Overall, then, although the tables presented in this section do not permit us to distinguish between alternative theoretical views of the relationship between population growth and employment, they do not paint a particularly dire picture of developing countries' labor absorption prospects. The evidence of the rapid growth of the size of the nonagricultural sectors, and of the growing productivity of workers in those sectors, suggest that developing countries have, in fact, been able to absorb considerable additions to their populations into productive employment. Although the road ahead does look rockier for the low-income developing countries than for the middle-income developing countries, labor market structures in both groups of economies seem to be geared-up for at least some further expansion. 


\section{Country-Specific Experiences [26]}

In the preceding three sections, we presented a broad overview of the central relationships between population growth, labor supply, and employment in developing countries. We also reviewed aggregate indicators of many of those relationships using data for different income and geographic groups of countries. An important caveat to those sections is that they reflect general tendencies, and not necessarily the experience of any particular country. In other words, a particular country's culture, labor market institutions, international trade policies, stock of natural resources, etc., may have considerable influence on the extent to which (1) population growth leads to increased labor supply and (2) increased labor supply is absorbed into productive employment. The purpose of this section is to document this claim with examples of the recent labor market experiences of a selected number of developing countries. Identifying all of the country-specific factors that can influence labor absorption is beyond the scope of this paper, but we will try to list some of the main ones and to provide illustrative examples. In this connection, we will focus on the role played by (1) external sources of demand for a particular economy's labor; (2) the availability of land and other natural resources; and (3) governmental policies which directly or indirectly impinge on the labor market.

In the simple theoretical models of developing country labor markets outlined in earlier sections, it was assumed that the economies were closed, i.e., that all labor absorption would take place domestically. However, the recent experience of several developing countries demonstrates that, to a substantial extent, this need not be the case in practice. For example, the 
economies of India, the Philippines, and Egypt have all been affected by the substantial emigration of their resident labor forces to the oil-rich Arab economies. To illustrate, it is estimated that there were 1-2 million Egyptians working abroad at the beginning of this decade, a magnitude equal to between 10 and 20 percent of Egypt's resident labor force. This massive emigration has both positive and negative implications for the Egyptian economy. On the positive side, the substantial absorption of labor into relatively high-wage employment externally, has resulted in a sharp decline in agricultural employment, accompanied by an increase in agricultural wages and the onset of a trend toward capital intensity and higher productivity in agricultural production. In addition, these high-wage emigrants (the majority of them being skilled construction workers) have tended to remit substantial portions of their earnings to their relatives in Egypt (with remittances alone amounting to 10 percent of Egypt's GNP in 1980), thereby providing a major source of foreign exchange and a major stimulus to domestic demand. [27] On the other hand, the massive emigration of Egyptian labor has increased the dependence of the Egyptian economy on the world price of $0 i l$ and on the construction boom in the Arab countries. Moreover, it appears that the structural transformation of Egyptian agricultural production has reduced its labor absorption capacity, which could be important under conditions of massive return migration.

A second key factor affecting the labor absorption capacity of a developing economy is the size and characteristics of its stock of idle land and other natural resources. In particular, labor absorption in developing economies is generally associated with a transition from predominantly agricultural to nonagricultural production and employment. However, the agricultural sectors of several developing economies have exhibited great labor absorption capacity. A 
good example is Mexico, which experienced a five-fold increase in the area of its land under cultivation from 1940 to 1970; Mexico also experienced rapid population growth during those years and growth of GNP per capita that was above the average for countries in its income group. However, starting in the late 1960's, Mexico's safety valve for labor absorption began to close up as the supply of unfarmed arable land in Mexico began to disappear. As a consequence, growth of GNP per capita was below average for Mexico in the 1970's. Moreover, population and labor force growth in Mexico have continued to be substantial and have resulted in fairly massive increases in rural-urban migration. Indeed, this migration far exceeds the absorptive capacity of the industrial sector of the Mexican economy and has resulted in the swelling of the informal urban sector and the steady flow of both legal and $i l$ legal emigration to the United States. Thus, Mexico no longer seems to provide an excellent counterexample to the pessimistic view that population growth hinders development (see Coale, 1978).

Another country that seems to be enjoying some degree of development despite rapid population growth is Kenya, a low-income developing country that had a population growth rate of 4.0 percent from 1970-82. Labor absorption in Kenya has been high, despite industrial wage levels that are considerably higher than agricultural sector wages, and the presence of substantial urban unemployment. To a large extent, Kenyan development reflects the continuing availability of unfarmed arable land and the sizeable magnitude of foreign exchange that is generated through tourism (and the substantial growth of an informal urban sector). Indeed, GNP per capita in Kenya increased 2.3 percent per year from 1955-1983, in contrast to the experience of the bordering countries of Somalia, Ethiopia, Tanzania, and Uganda, which had growth rates of 
-0.8 percent, 0.5 percent, -0.9 percent, and -4.4 percent, respectively, over the same period (and 1970-82 population growth rates of 3.1 percent, 2.7 percent, 3.2 percent, and 3.1 percent, respectively).

Although some countries may be able to facilitate labor absorption by bringing additional land under cultivation, other countries may already be too densely populated to make that a viable option. Examples of such countries include India and Indonesia. In these countries, however, labor absorption can be facilitated by changes in agricultural technology. For example, in the Punjab region of India, the labor-intensive "Green Revolution" has resulted in an expansion of both agricultural output and employment. Similarly, in Indonesia, the traditional rice economy has been transformed by the use of (relatively labor-intensive) high-yielding varieties of rice and by the growing practices of double- and triple-cropping.

In Brazil, by contrast, where population density is modest, the productivity of agricultural labor was increased by the adoption of more efficient agricultural production techniques rather than by increased land cultivation, thereby releasing labor to other sectors and compounding the absorption problem. In fact, employment in Brazil seems to have kept pace with increased labor supply, although apparently at the expense of real wages, which have fallen over time. The Philippines is another example of a country in which absorption has been achieved at the expense of falling real wages.

In addition to land, oil is another natural resource that can (and has) figured quite prominently in the absorption ability of developing economies. Here, we cite Indonesia, Venezuela, and Mexico as examples of countries who either export, or have the capacity to export, oil in international markets. To the extent that oil exports contribute to the generation of foreign exchange, 
they can provide an important boost to capital formation and the expansion of industrial employment in developing economies. On the other hand, oil dependency can greatly hinder the pace and stability of a country's development. For example, many of the balance-of-payments problems in the Philippines, which have affected economic growth and labor absorption through their affects on domestic capital markets and government monetary and fiscal policies, have been traced to variations in world oil prices.

The final factor conditioning the labor absorption capacity of individual developing economies to which we would like to draw attention is governmental policy impacting on the labor market. Earlier, we noted the importance of government-established minimum wages in creating growth-inhibiting distortions in an economy. Here, we mention another government policy aimed directly at increasing labor absorption: public employment programs. One example of a country in which such programs have been heavily relied upon is Egypt. Excluding the military, public employment in Egypt increased at an annual rate of nearly 7 percent between 1966 and 1978. This trend is largely the consequence of the government's establishment of employment guarantees for university graduates (since 1966) and military conscripts (from 1973 to 1976). This policy, which resulted in substantial labor absorption at a time when Egypt was still a classic surplus labor economy (i.e., before the massive emigration of Egyptian labor to the oil-rich Arab countries), appears to be constraining productivity growth under the current circumstances of labor scarcity since government workers have relatively low productivity. This highlights the point that it is not simply employment that matters, but employment in productive jobs. 
Another set of government policies deserving of mention are those that relate to the relative price of capital. In an effort to stimulate the growth of industry, a number of developing countries have adopted aggressive fiscal and monetary policies that tend to induce a capital bias in their overall development pattern. For example, Brazil, Indonesia, and the Philippines have all had macroeconomic policies that provided incentives for private companies to borrow from abroad or forced the central government to borrow heavily to cover a deficit. As a consequence, economic conditions in these countries have been highly sensitive to the state of world capital markets and relatively capital-intensive patterns of development have been induced. In contrast, other developing countries such as India (and both Brazil and the Philippines in past years) have pursued more conservative monetary and fiscal policies in concert with import substitution strategies designed to impart internal stability to their economic systems and to promote long-run growth and labor absorption. Foreign exchange restrictions, which can be used to depress the importation of capital, can also help to promote labor absorption.

Finally, many developing countries have intervened in agricultural markets, often purchasing output from farmers and providing low-cost food for urban dwellers. These policies can affect the allocation of labor among sectors, rural-urban migration, and the success of adjusting to population increases. As yet, there has been no definitive study of the effects of food price policy (or capital price policy) on the overall success of countries in absorbing labor into productive jobs. 


\section{Conclusions and Speculations About the Future}

This review of evidence has shown that developing countries have faced an enormous increase in population in the past two decades. Fertility and mortality patterns guarantee a similar large increase in the future. The experience of the past indicates, however, that despite population increasing more than the labor force, and despite inefficient dualistic labor markets due potentially to government-induced and other imperfections, developing countries were, on the whole, relatively successful in improving their economic positions over the period. The labor markets absorbed a "huge" population increase, with per worker incomes rising and shifts taking place in the labor force distribution toward more productive sectors of the economy. Our analysis has also highlighted the wide range of country experiences in population growth, in labor market policies likely to influence "absorption" in modern sectors, and ultimately in the likely impact of population growth on per capita incomes. Overall, the experiences of the 1960-1980 period tend to be more supportive of an optimistic view of the ability of developing economies to adjust to population growth, than of a pessimistic view.

What about the future?

Simply because the developing economies managed to raise productivity and shift employment into the service and manufacturing sectors in the 1960-80 period does not necessarily mean that they will be able to do so in the next two decades. We consider next the factors likely to make absorption of the increased population easier and those likely to make it more difficult in the 1980-2000 period. 
To begin with, consider the projected population and labor force growth rates in Table 14. The figures here show two advantages compared to the 1960-80 period examined in Table 1. First, rates of population growth will be smaller than in the earlier periods: for all low-income developing countries the rates of growth fall from 2-3 percent (1960-70) and 1.9 percent (1970-82) to a projected 1.7 percent. The rate of population increase also falls for lowerand upper middle-income developing countries. Second, in sharp contrast to the earlier period, the labor force will increase more rapidly than population in all types of economies. For the first time in recent years, dependency rates will be getting lower. Hence, smaller increases in income per worker will be needed to produce any given increase in income per capita.

On the negative side are the absolute magnitudes of the increases noted at the outset of the paper. From 1960 to 1982, labor supply in less developed countries grew by 173 million workers. From 1980 to 2000 , supply will increase by 255 million workers. In lower middle-income developing countries the absolute growth in labor force will rise from 50 million (1960-82) to 84 million (1980-2000) while in upper middle-income countries the increase will be from 35 million (1960-82) to 59 million (1980-2000). [28] To be productive, these workers must be equipped with both material and human capital. In absolute magnitudes, this growth will place great demands on world capital markets (both public and private) and thus on world savings behavior. To the extent that less developed countries rely on capital flows from more developed countries they will, in turn, require greater per capita investments from those countries.

In our view, if modern technology is applied to less developed countries at the same rate as in the past two decades -- which presumably requires both human and physical capital investments of enormous absolute magnitudes but of 
comparable relative magnitudes to the past -- Malthusian disasters will not necessarily be the result of forecasted population growth. However, on the basis of past history, the middle-income developing countries are likely to perform better in this respect than the low-income countries, some of whom may need considerable help if they are to absorb increased population while shifting labor to more productive sectors and raising output per worker. 
Notes

1. By developed countries we mean Western Europe, Australia, Japan, Canada, and the United States, as indicated in Appendix Table A.2. Except for countries with mid-1982 populations below one million, high-income oil exporters, and East European nonmarket economies, all other countries are considered less developed, despite the wide range of industrialization and income per capita among them.

2. These figures are taken from the World Development Report 1984 and from the Population Reference Bureau's 1984 World Population Data Sheet.

3. See Simon (1981) for a presentation of the optimists' point of view; see Coale and Hoover (1958) for a statement of the pessimists' view.

4. For such correlations see Kuznets (1973, p. 43) who reports the rank correlation between the rate of growth of population and per capita product as -.31 for a 11 countries and .11 for all underdeveloped countries.

5. See Standing, 1976 for an excellent discussion of this issue; see also Dixon, 1982 and Anker, 1983 for thorough treatments of the problems involved in measuring the labor force participation of women in developing countries.

6. This simple insight into the dynamic relationship between population and labor force growth underlied some of the main results derived in one of the earliest neoclassical treatments of the relationship between population and economic growth, the classic volume by Coale and Hoover (1958).

7. One can think of individuals choosing to migrate to urban areas in response to fertility or mortality changes which affect the benefits and costs of such 
migration. See Stark and Bloom (1985) for a review of recent developments in the migration literature. See Williamson (1986) for some discussion of age selectivity in migration.

8. See Durand (1975) for a thorough empirical study of labor force participation rates in less developed economies.

9. See Freeman and Bloom (1985) for a review of this literature and for some new empirical results.

10. See Chenery and Syrquin (1975) for an attempt to characterize "average" patterns of development. Note, however, that Chenery and Syrquin do not focus on deviations from those average patterns, which are substantial. Nor do they focus on empirical testing of theoretical relationships between the variables in their analysis.

11. See Ranis and Fei (1984) for further discussion of this point.

12. In this model, the average product of labor in the agricultural sector will, of course, increase somewhat as more labor is drawn into the modern sector. This will tend to raise wages in the modern sector in the simple model out 1 ined here.

13. Further references to theoretical models of dual economies include Jorgensen, 1961; Fei and Ranis, 1964; and Dixit, 1973.

14. This conclusion rests, of course, on the assumption that the savings rate from industrial sector wages is less than that from profits. If this assumption is reasonable, labor market market imperfections in the modern sector will constrain the economy's ability to absorb new labor. 
15. Gregory (1975, p. 121).

16. Berg (1970, p. 296).

17. Webb (1977, p. 246).

18. House and Rempel (1976).

19. Webb (1977, pp. 237-8).

20. Krueger (1983, pp. 146-7).

21. According to McNicoll, "...there is strong evidence of population-induced innovation in some agricultural settings; but there are cases too where rapid population growth has been accompanied by stagnant productivity or by labor-saving rather than labor-using technical progress." (1984a, p.197)

22. Indeed, at the level of casual empiricism, this theory is not inconsistent with the emergence of the urban informal sector. See Portes and Benton, 1985.

23. Since much agricultural production in developing countries is not exchanged, the World Bank has imputed part of its value for many countries.

24. Ideally, we would also analyze the wage effects of rapid population growth. Unfortunately, the sketchy and unreliable nature of wage data for most developing countries render such an analysis beyond the scope of this paper. However, we will analyze variations in a kindred measure -- output per worker -across sectors and over time.

25. See Kuznets (1984) for a detailed analysis of the decline of agricultural employment. 
26. The material presented in this section draws heavily on the studies by Alba (1984), Hansen and Radwan (1982), International Labour Office (1972), Leiserson (1980), Lluch and Mazumdar (1983), McNicoll (1984b), Paiva (1984), Paqueo (1984), Radwan (1984), and Visaria (1984).

27. See Lucas and Stark (1985) for an interesting analys is of immigrant remittances.

28. These figures are extracted from Wor ld Bank, wor ld Development Report 1984, p. 148 and p. 218 . 
References

Alba, F. 1984. "Country Case Studies. Mexico: Achievements and Limitations in Labor Force Absorption." Unpublished paper presented at the Bellagio, Italy conference on "Population Growth and Labor Absorption in the Developing World: 1960-2000".

Anker, R. 1983. "Female Labour Force Activity in Developing Countries: A Critique of Current Definitions and Data Coliection Methods." International Labour Review 122: 709-723.

Berg, E. 1970. "Wage Structures in Less Developed Countries." In Wage Policy Issues in Economic Development. Smith, A.B., Ed., London: Macmillan. Binswanger, H.P. 1979. "Induced Technical Change: Evolution of Thought." In Binswanger, H.P. and V.W. Ruttan, Eds., Induced Innovation: Technology, Institutions, and Development. Baltimore: Johns Hopkins University Press. Boserup, E. 1981. Population and Technological Change--A Study of Long-Term Trends. Chicago: University of Chicago Press.

Chenery, H. and M. Syrquin. 1975. Patterns of Development, 1950-70. London: Oxford University Press.

Coale, A.J. 1978. "Population Growth and Economic Development: The Case of Mexico." Foreign Affairs: 415-29. and E.M. Hoover. 1958. Population Growth and Economic Development in Low-Income Countries. Princeton, New Jersey: Princeton University Press.

Dixit, A. 1970. "Models of Dual Economies." In Mirrlees, J.A. and N.H. Stern, Eds. Models of Ecoriomic Growth. New York: John Wiley, 327-352. Dixon, R.B. 1982. "Women in Agriculture: Counting the Labor Force in 
Developing Countries." Population and Development Review 8: 539-566.

Durand, J.D. 1975. The Labor Force in Economic Development: A Comparison

of International Census Statistics: 1946-66, Princeton, New Jersey:

Princeton University Press.

Fei, J.C.H. and G. Ranis. 1964. Development of the Labor Surplus Economy. Homewood, Illinois: Irwin.

Freeman, R.B. and D.E. Bloom. 1985. "The Youth Problem: Age or Generational Crowding?" Unpublished Report to the OECD. December.

Gregory, P. 1975. "The Impact of Institutional Factors on Urban Labor Markets." In Studies in Employment and Rural Development. Washington: Wor ld Bank.

Harris, J. and M.P. Todaro. 1970. "Migration, Unemployment, and Development:

A Two-Sector Analysis." American Economic Review 60: 126-142.

Hansen, B. and S. Radwan. 1982. Employment Opportunities and Equity in a

Changing Economy: Egypt in the 1980s. Geneva: International Labour Office.

Hayami, Y. and V.W. Ruttan. 1985. Agricultural Development. Baltimore: Johns Hopkins University Press.

Heller, P.S. and A.A. Tait. 1983. "Government Employment and Pay: Some International Comparisons." International Monetary Fund Occasional Paper No. 24. Washington, D.C.

Hirschman, A.0. 1958. The Strategy of Economic Development. New Haven: Yale University Press.

House, W.J. and H. Rempe1. 1976. "The Impact of Unionization on Negotiated Wages in the Manufacturing Sector in Kenya." Oxford Bulletin of Economic Statistics 38 . 
Instituto Nacional de Estadisticas. 1977. Chile: Anuario Estadisticas, 1976. Santiago.

International Labour office. Yearbook of Labour Statistics. 1975, 1981, and 1984 Editions. Geneva: International Labour office.

International Labour Office. 1972. Employment, Incomes, and Equality: A

Strategy for Increasing Productive Employment in Kenya. Geneva: International Labour office.

Jorgenson, D.W. 1961. "The Development of a Dual Economy." Economic Journal LXXI: 309-334.

Krueger, A. 0. 1983. Trade and Employment in Developing Countries, 3 : Synthesis and Conclusions. Chicago: University of Chicago Press. Kuznets, S. 1965. Economic Growth and Structure: Selected Essays. New York: Norton. . 1973. Population, Capital, and Growth. London: Heinemann Educational Books. - 1984. "The Pattern of Shift of Labor Force from Agriculture, 1950-70." In Gersovitz, M., C.F. Diaz-Alejandro, G. Ranis, and M.R. Rosenzweig, Eds., The Theory and Experience of Economic Development. London: George Allen and Unwin. 44-59. Leibenstein, H. 1978. General X-Efficiency Theory and Economic Development. New York: Oxford University Press. Leiserson, M. and others. 1980. Employment and Income Distribution in Indonesia. Washington: The World Bank. Lewis, W.A. 1954. "Economic Development with Unlimited Supplies of Labour." Manchester School 22: 137-91. 
. 1958. "Unlimited Labour: Further Notes." Manchester School

26: $1-32$.

Lluch, C. and D. Mazumdar. 1983. Wages and Employment in Indonesia. Washington: The World Bank.

Lucas, R.E.B. and 0. Stark. 1985. "Motivations to Remit: The Case of Botswana." Journal of Political Economy.

MCNicol1, G. 1984a. "Consequences of Rapid Population Growth: An Overview and Assessment." Population and Development Review 10:177-240.

- 1984b. "Population Dynamics and Labor Absorption in Indonesia:

A Case Study." Unpublished paper presented at the Bellagio, Italy conference on "Population Growth and Labor Absorption in the Developing Wor 1d: 1960-2000".

Paiva, P. 1984. "Fifty Years of Population Growth and Labor Absorption in Brazil: From 1950 to 2000." Unpublished paper presented at the Bellagio, Italy conference on "Population Growth and Labor Absorption in the Developing World: 1960-2000".

Paqueo, V. B. 1984. "Population Growth, Employment and Total Factor Productivity Growth: Problems and Prospects of the Philippine Political Economy." Unpublished paper presented at the Bellagio, Italy conference on "Population Growth and Labor Absorption in the Developing World: 1960-2000".

Portes, A. and L. Benton. 1984. "Industrial Development and Labor Absorption: A Reinterpretation." Population and Development Review 4: 589-611.

Radwan, S. 1984. "The Labour Markets in an Open Economy: Egypt." Unpublished paper presented at the Bellagio, Italy conference on "Population Growth and Labor Absorption in the Developing World: 1960-2000". 
Ranis, G. and J.C. Fei. 1984. "Lewis and the Classicists." In Gersovitz, M., C.F. Diaz-Alejandro, G. Ranis, and M.R. Rosenzweig, Eds., The Theory and Experience of Economic Development. London: George Allen and Unwin. $31-42$.

Sen, A.K. 1968. Choice of Techniques. Oxford: Basil Blackwell. Simon, J. 1981. The Ultimate Resource. Princeton: Princeton University Press.

Squire, L. 1981. Employment Policy in Developing Countries. Washington: The Wor ld Bank.

Standing, G.M. 1976. "Concepts of Labour Force Participation and Underutilisation." International Labour Office, Population and Employment Working Paper No. 40, Geneva.

- 1978. Labour Force Participation and Development. Geneva:

International Labour office. and G. Sheehan, Eds. 1978. Labour Force Participation in

Low-Income Countries. Geneva: International Labour office.

Stark, O. and D.E. Bloom. 1985. "The New Economics of Labor Migration." American Economic Review: Papers and Proceedings.

Starr, G. 1981. Minimum Wage Fixing. Geneva: International Labour office.

United Nations. Yearbook of Industrial Statistics. 1968 to 1980 Editions. New York: United Nations.

U.S. Department of Labor. 1983. Handbook of Labor Statistics. Washington, D.C.: U.S. Government Printing Office.

Visaria, P. 1984. "The Growth of Population and Labour Force in India: 1961-2001." Unpublished paper presented at the Bellagio, Italy conference 
on "Population Growth and Labor Absorption in the Developing Wor Id: 1960-2000".

Webb, R.C. 1977. "Wage Policy and Income Distribution in Developing Countries." In Income Distribution and Growth in the Less Developed Countries. Frank, C.R. and R.C. Webb, Eds. Washington: Brookings Institution.

Wiliamson, J.G. 1986. "Migration and Urbanization." In Handbook of Development Economics. H. Chenery and T.N. Srinivasan, Eds. Forthcoming. Wor ld Bank. 1984. World Development Report 1984. Oxford: Oxford University Press.

World Bank. 1983. World Tables. Volume II. Social Data. Oxford: Oxford University Press. 


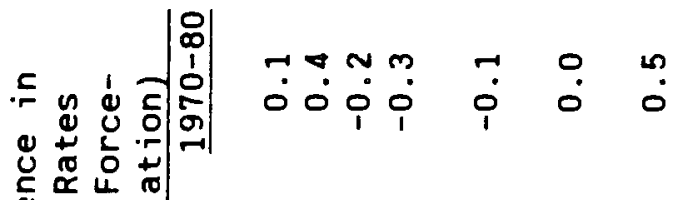

둔

In

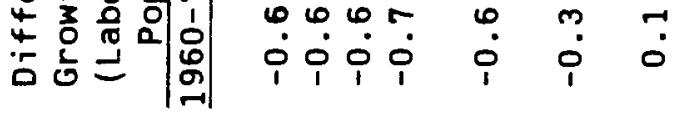

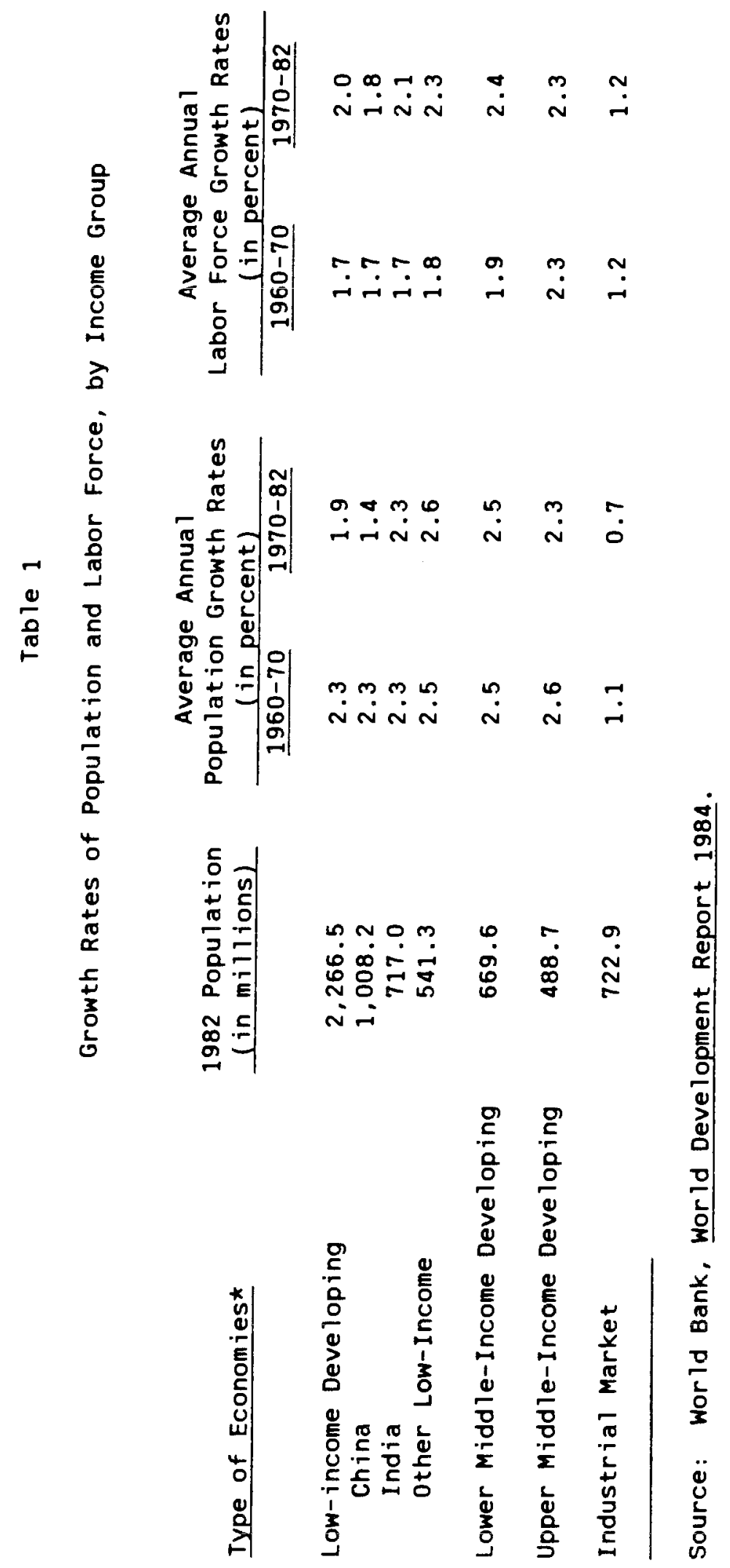




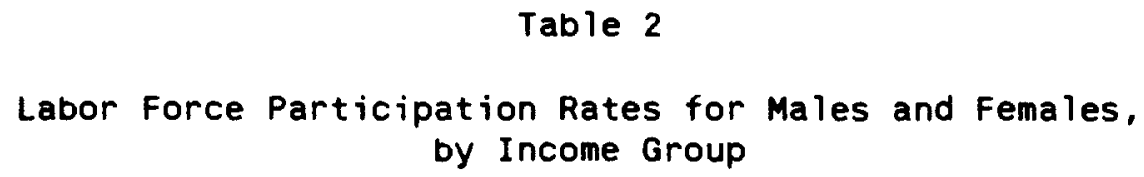

Type of Economy

Low-Income Developing

Middle-Income Developing

Industrial Market

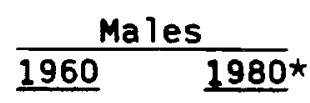

$56.6 \quad 54.4$

53.4

59.2
49.4

59.0

\begin{tabular}{|c|c|}
\hline \multicolumn{2}{|c|}{ Females } \\
\hline 1960 & $1980 *$ \\
\hline 31.5 & 29.5 \\
\hline 19.5 & 19.7 \\
\hline 27.0 & 32.5 \\
\hline
\end{tabular}

Source: World Bank, World Tables, Volume II, Social Data, 1983. *Circa 1980. 
Labor Force Participation Rates for Males and Females,

by Geographic Region and for Selected Countries

Developing Economies (All ages)

Region

Africa South of Sahara

Middle East and North Africa

East Asia and Pacific

South Asia

Lat in America and Caribbean

South Europe

Deve loped Economies (Ages 15t)

\section{Country}

United States

Canada

Australia

Japan

France

Germany

Great Britain

Italy

Sweden

\section{(Ages 15t)}

$\frac{\text { Males }}{\underline{1960} \underline{1980}}$

$55.3 \quad 50.2$

$51.6 \quad 45.4$

$55.3 \quad 55.5$

$57.1 \quad 52.0$

52.9

49.8

$60.3 \quad 55.2$

31.8

28.1

4.5

5.6

34.5

33.5

24.4

22.8

12.5

14.8

60.3 


\begin{tabular}{lcc}
\multicolumn{3}{c}{ Table 4} \\
Percent of Population Aged & 15-64, by Income Group \\
Type of Economies & 1960 & 1982 \\
\hline Low-Income Developing & 55 & 59 \\
China & 56 & 63 \\
India & 54 & 57 \\
Other Low-Income & 54 & 53 \\
Lower Middle-Income Developing & 54 & 55 \\
Upper Middle-Income Developing & 55 & 57 \\
Industrial Market & 63 & 66
\end{tabular}

Source: Wor ld Bank, World Development Report 1984. 
Table 5

Ratio of Average Agricultural to Average Manufacturing Wages

\begin{tabular}{|c|c|c|c|}
\hline Country & 1968 & 1974 & 1979 \\
\hline Argentina & $0.64^{1.2}$ & $0.64^{1,2,3}$ & $0.69^{4}$ \\
\hline Barbados $^{1}$ & 0.66 & 0.71 & -- \\
\hline Burma & $1.31^{1}$ & $1.21^{1}$ & 1.22 \\
\hline Colombia & $0.38^{1}$ & $0.42^{5}$ & 0.46 \\
\hline Costa Rica ${ }^{2}$ & -- & 0.50 & 0.50 \\
\hline Chile $e^{1,2}$ & 0.26 & $0.21^{3}$ & 0.34 \\
\hline Cyprus $^{1}$ & 1.24 & 1.10 & 0.71 \\
\hline El Salvador ${ }^{1}$ & -- & 0.30 & 0.30 \\
\hline Guyana & $0.97^{1}$ & $0.84^{1}$ & 0.72 \\
\hline Malawi & 0.33 & 0.29 & 0.28 \\
\hline Mauritius & 0.97 & 1.31 & 1.52 \\
\hline Mexico ${ }^{2}$ & $0.31^{1}$ & $0.33^{6}$ & 0.37 \\
\hline Morocco 1,2 & 0.51 & 0.30 & -- \\
\hline Sri Lanka 1 & 0.44 & 0.41 & 0.53 \\
\hline Syria ${ }^{2}$ & $0.75^{7}$ & 0.40 & $0.39^{4}$ \\
\hline Zambia ${ }^{8}$ & 0.55 & 0.41 & $0.42^{4}$ \\
\hline
\end{tabular}

Source: International Labour Office; Yearbook of Labour Statistics, 1975 and 1981, Geneva.

1 Males only.

2 Minimum rates.

41973.

51977.

61976.

7975 .

81969 .

8 Zambian nationals only. 
Table 6

Cross Section Variation in Minimum Wages

\begin{tabular}{|c|c|c|c|c|c|c|}
\hline \multirow[b]{2}{*}{ Country } & \multirow[b]{2}{*}{ Year } & \multirow[b]{2}{*}{ Minimum } & \multicolumn{2}{|c|}{ Wor ld Bank } & \multicolumn{2}{|c|}{ ILO } \\
\hline & & & Avg. Manuf. & Ratio & Avg. Manuf. & Ratio \\
\hline $\begin{array}{l}\text { Algeria } \\
\text { (dinars/h.) }\end{array}$ & 1975 & 2.08 & -- & -- & 3.13 & 0.66 \\
\hline $\begin{array}{l}\text { Argentina } \\
\text { (peso/m.) }\end{array}$ & 1976 & 7608 & -- & -- & $12,896.00$ & 0.59 \\
\hline $\begin{array}{l}\text { Brazil } \\
\quad(\text { cruzeiro/m.) }\end{array}$ & 1974 & 355 & 1151.34 & 0.31 & -- & -- \\
\hline $\begin{array}{l}\text { Cameroon } \\
\text { (CFA/h.) } \\
\text { Central African }\end{array}$ & 1976 & 64 & 188.24 & 0.34 & -- & -- \\
\hline $\begin{array}{l}\text { Republic } \\
(\mathrm{CAF} / \mathrm{h} .)\end{array}$ & 1976 & 35.60 & 135.56 & 0.26 & -- & - \\
\hline $\begin{array}{l}\text { Colombia } \\
\text { (peso/m.) }\end{array}$ & 1977 & 1573 & $7,090.98$ & 0.22 & $4,005.30$ & 0.39 \\
\hline $\begin{array}{l}\text { Costa Rica } \\
\left(\text { colones } / m_{.}\right)\end{array}$ & 1975 & 585 & $1,001.52$ & 0.58 & $1,123.00$ & 0.52 \\
\hline $\begin{array}{l}\text { Ecuador } \\
\text { (sucres/m.) }\end{array}$ & 1977 & 1500 & $4,494.01$ & 0.33 & $4,022.20$ & 0.37 \\
\hline $\begin{array}{l}\text { El Salvador } \\
(\text { culones/m.) }\end{array}$ & 1977 & 186 & 386.36 & 0.48 & $297.44^{1}$ & 0.62 \\
\hline $\begin{array}{l}\text { Egypt } \\
\qquad(p \text { iastre/d.) }\end{array}$ & 1976 & 40 & 153.85 & 0.26 & 108.11 & 0.37 \\
\hline $\begin{array}{l}\text { Ghana } \\
\text { (pesewa/d.) }\end{array}$ & 1977 & 400 & 781.26 & 0.51 & -- & -- \\
\hline $\begin{array}{l}\text { Guatema la } \\
\text { (guetzal/m.) }\end{array}$ & 1975 & 57 & 177.31 & 0.49 & 93.69 & 0.61 \\
\hline $\begin{array}{l}\text { Ivory Coast } \\
(\text { CFA/h.) }\end{array}$ & 1977 & 115 & 289.40 & 0.40 & -- & -- \\
\hline $\begin{array}{l}\text { Kenya } \\
\quad(\text { shillings/m.) }\end{array}$ & 1977 & 350 & 977.82 & 0.36 & 978.30 & 0.36 \\
\hline $\begin{array}{l}\text { Libya } \\
\text { (dinars/d.) }\end{array}$ & 1976 & 2.00 & 4.24 & 0.47 & -- & - \\
\hline $\begin{array}{l}\text { Mexico } \\
\quad(\text { peso/m.) }\end{array}$ & 1977 & 2766 & $6,832.36$ & 0.40 & $4,984.20$ & 0.55 \\
\hline $\begin{array}{l}\text { Panama } \\
\text { (balboa/m.) } \\
\text { Papua, }\end{array}$ & 1977 & 114 & 295.59 & 0.39 & 237.21 & 0.48 \\
\hline $\begin{array}{l}\text { New Guinea } \\
\text { (kina/w.) }\end{array}$ & 1977 & 28.46 & 58.30 & 0.49 & -- & -- \\
\hline $\begin{array}{l}\text { Peru } \\
\qquad\left(501 / m_{.}\right)\end{array}$ & 1975 & 3270 & $10,784.99$ & 0.30 & $5,525.00$ & 0.59 \\
\hline
\end{tabular}


Table 6, Continued

\begin{tabular}{|c|c|c|c|c|c|c|}
\hline \multirow[b]{2}{*}{ Country } & \multirow[b]{2}{*}{ Year } & \multirow[b]{2}{*}{ Minimum } & \multicolumn{2}{|c|}{ Wor ld Bank } & \multicolumn{2}{|l|}{ ILO } \\
\hline & & & Avg. Manuf. & Ratio & Avg. Manuf. & Ratio \\
\hline $\begin{array}{l}\text { Philippines } \\
\text { (peso/d.) }\end{array}$ & 1977 & 15.18 & 27.99 & 0.54 & -- & -- \\
\hline $\begin{array}{l}\text { Sri Lanka } \\
\text { (rupee/d.) }\end{array}$ & 1977 & 8.96 & - & - & 19.05 & 0.47 \\
\hline $\begin{array}{l}\text { Tanzania } \\
\quad(\text { shillings/m.) }\end{array}$ & 1974 & 340 & 563.90 & 0.60 & -- & -- \\
\hline $\begin{array}{l}\text { Tunisia } \\
\text { (dinar/h.) }\end{array}$ & 1977 & 0.193 & 0.45 & 0.43 & -- & -- \\
\hline $\begin{array}{l}\text { Uruguay } \\
\text { (new peso/m.) }\end{array}$ & 1977 & 312.2 & 504.12 & 0.62 & -- & - \\
\hline $\begin{array}{l}\text { Zambia } \\
\quad \text { (angwee/h.) }\end{array}$ & 1975 & 16 & 62.92 & 0.25 & 47.05 & 0.34 \\
\hline $\begin{array}{l}\text { Turkey } \\
\text { (lira/d.) }\end{array}$ & 1977 & 60.00 & 238.58 & 0.25 & 127.52 & 0.47 \\
\hline
\end{tabular}

Sources: Minimum Wages:

- Starr, Gerald, Minimum Wage Fixing, International Labour Office, Geneva, 1981.

- For Chile: Instituto Nacional de Estadisticas, Republica de Chile, Chile: Anvario Estadistico, 1976. Santiago, 1977.

Manufacturing Wages:

- U.N. Yearbook of Industrial Statistics, 1968-1980 Editions.

- Industrial Surveys and Census of Various Countries.

- International Labour Office, Yearbook of Labour Statistics, $1981,1975$.

$1_{\text {Males only. }}$ 
Table 7

Public Sector Employment as Share of Nonagricultural Employment

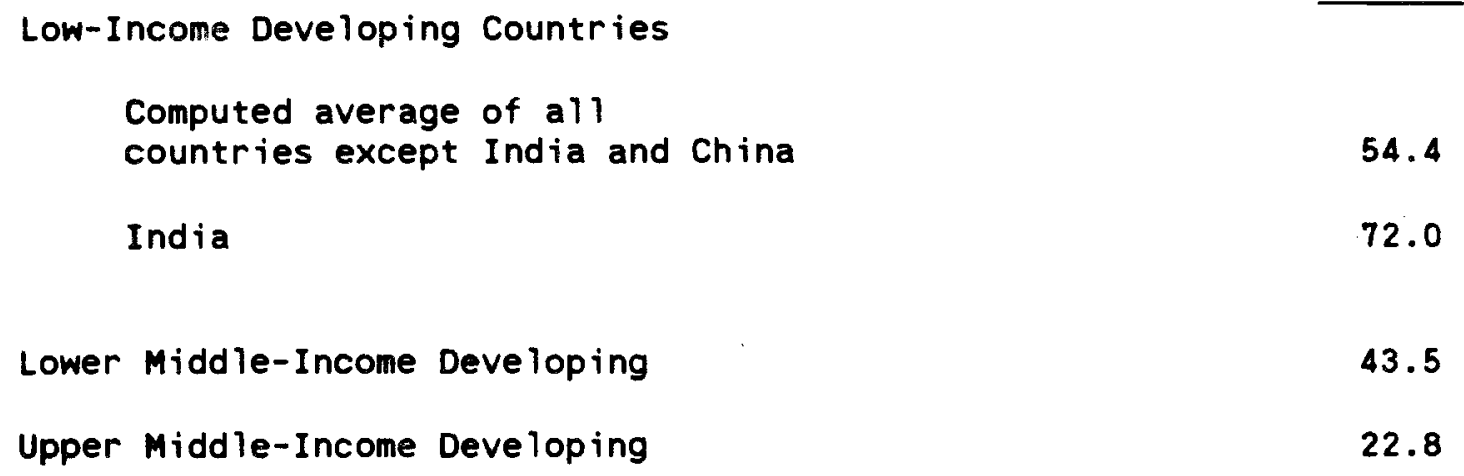

Source: Tabulated from "Government Employment and Pay: Some International Comparisons," Peter S. Heller and Alan A. Tait. Washington, D.C.: International Monetary Fund, Occasional Paper No. 24, October 1983. 


\section{Table 8}

Public Sector and Government Average Wage

Relative to Per Capita Income

\section{$\underline{1979-80}$}

Low-Income Developing Countries

6.61

(except India and China)

India

4.80

Lower Middle-Income Developing Countries

4.84

Upper Middle-Income Developing Countries

Source: Tabulated from "Government Employment and Pay: Some International Comparisons," Peter S. Heller and Alan A. Tait. Washington, D.C.: International Monetary Fund, Occasional Paper No. 24, October 1983. 
Table 9

Distribution of Labor Force Across Economic Sectors, by Income Group

\section{Type of Economies}

Low-Income Developing*

China

India

Other Low-income

Lower Middle-Income Developing

Upper Middle-Income Developing

Industrial Market

Percent of Labor Force in:

$\frac{\text { Agriculture }}{1960 \quad \underline{1980}}$

77

n.a.

74

82

71

49

18

\section{6}

$\frac{\text { Industry }}{1960 \quad \underline{1980}}$

9

n.a.

11

7

11

11

16

28

38

20
Services $\underline{1960}$

$\underline{1980}$

14 15

n.a. 12

15 16

11 16

18

31

44

56

Source: World Bank, World Tables, Volume II, Social Data, 1983.

*Figures for 1960 do not include data for China.

n.a.: not available. 


\section{Table 10}

Distribution of Labor Force Across Economic Sectors, by Geographic Region

\section{Region}

Africa south of Sahara

Middle East and North Africa

East Asia and Pacific*

South Asia

Latin America and Caribbean

South Europe

\begin{tabular}{|c|c|c|c|c|c|}
\hline \multicolumn{2}{|c|}{ Agriculture } & \multicolumn{2}{|c|}{ Industry } & \multicolumn{2}{|c|}{ Services } \\
\hline$\underline{1960}$ & 1980 & 1960 & 1980 & 1960 & $\underline{1980}$ \\
\hline 77.6 & 67.4 & 8.8 & 13.4 & 13.6 & 19.2 \\
\hline 58.6 & 42.4 & 16.1 & 27.8 & 25.3 & 29.8 \\
\hline 71.1 & 53.2 & 9.5 & 16.9 & 19.4 & 29.9 \\
\hline 74.4 & 68.9 & 10.6 & 13.2 & 15.0 & 17.9 \\
\hline 48.8 & 31.9 & 19.2 & 23.7 & 32.0 & 44.4 \\
\hline 64.0 & 40.7 & 17.3 & 23.4 & 18.7 & 35.9 \\
\hline
\end{tabular}

Percent of Labor Force in:

Source: World Bank, World Tables, Volume II, Social Data, 1983.

*Excludes China. 
Table 11

Gross Domestic Product Per Worker, For Each Sector Relative to the Economy, 1960-1980

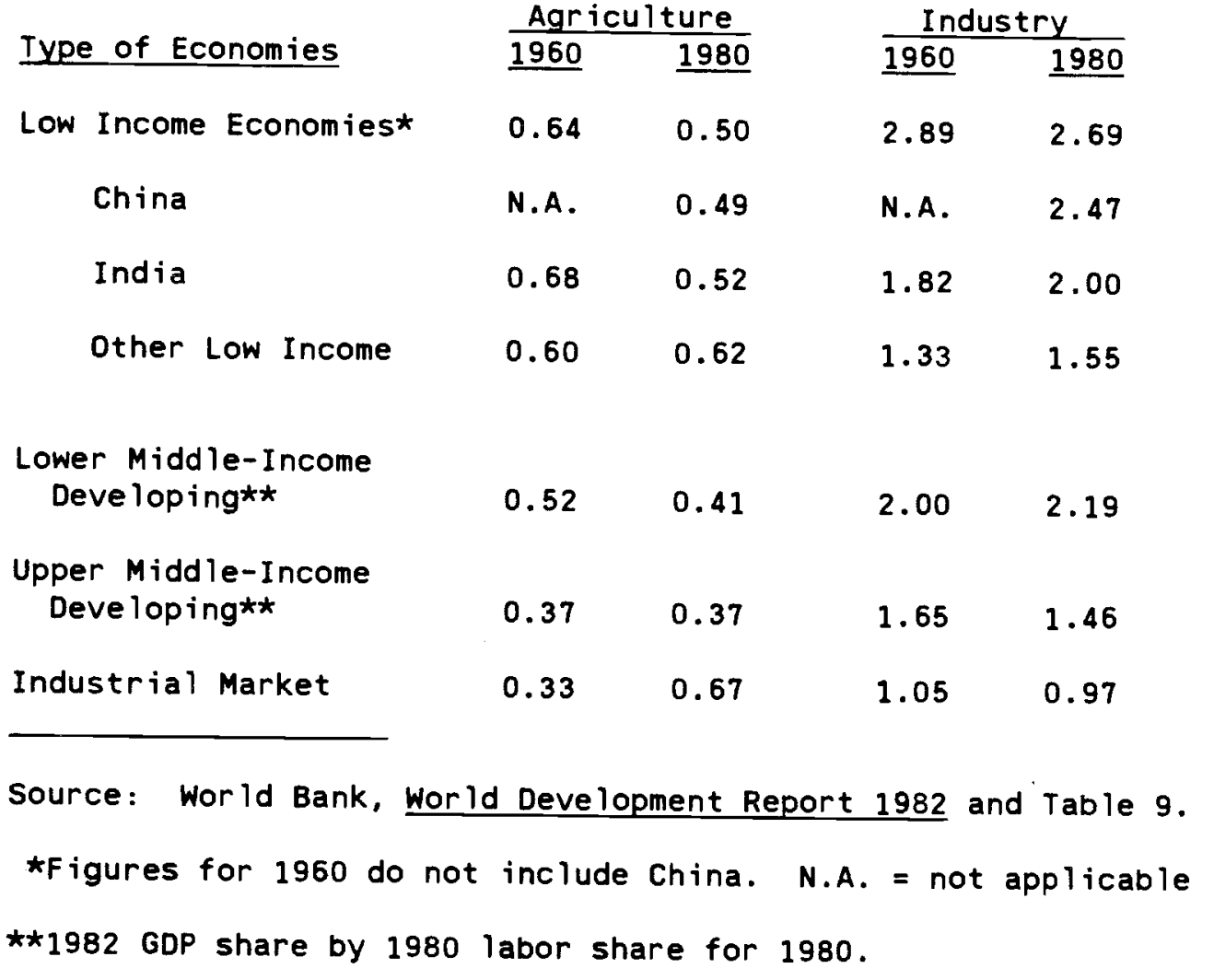

$\frac{\text { Agriculture }}{1960}$

$0.64 \quad 0.50$

N.A.

1.33

3.54

1.79

N.A.

2.00

2.31

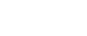

2.28

1.50

Lower Middle-Income

Upper Middle-Income

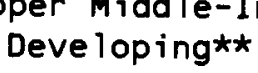

0.37

1.59

1.14

1.23

1.11

1980

1.93

1.83

2.38

50




\section{Table 12}

Estimates of the Contribution of Shifts in Sectoral Distribution of Labor to Growth of GDP Per Worker, 1960-1980

Type of Economy

Low Income Economies

China

India

Other Low-Income

Lower Middle-Income Developing

Upper Middle-Income Developing

Industrial Market

\begin{tabular}{|c|c|}
\hline \multicolumn{2}{|c|}{$\begin{array}{c}\text { Percentage Change in GDP } \\
\text { Per Worker Using }\end{array}$} \\
\hline $\begin{array}{l}1960 \text { Relative } \\
\text { GDP by Sector }\end{array}$ & $\begin{array}{l}1980 \text { Re lative } \\
\text { GDP by Sector }\end{array}$ \\
\hline
\end{tabular}

10.5

11.5

3.9

5.2

15.1

13.8

25.0

23.2

24.1

21.0

10.8

2.3

Source: Tables 9 and 11, calculated by applying 1980 distribution of labor force to 1960 relative GDPs per worker and 1960 distribution of labor force to 1980 relative GDPs per worker. 


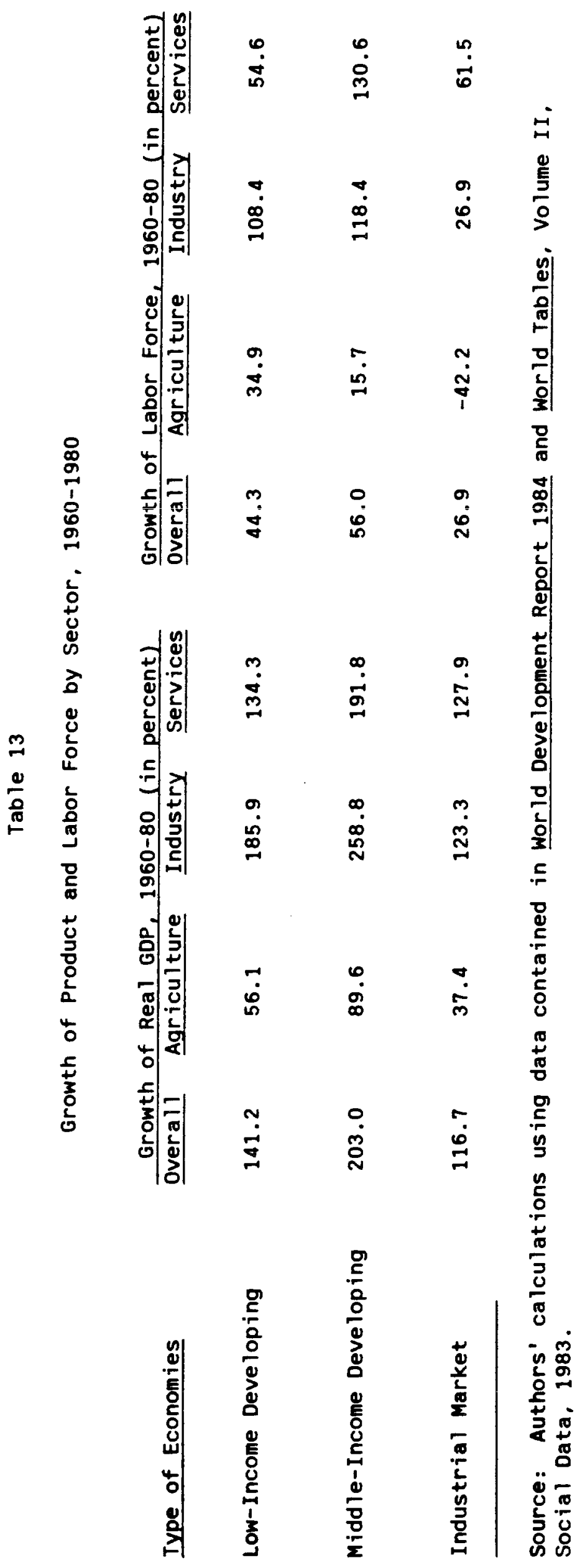


Table 14

Projected Population and Labor Force Growth Rates 1980-2000,

by Income Group

\begin{tabular}{|c|c|c|c|}
\hline Type of Economies & Population & Labor Force & Difference \\
\hline Low-Income Developing & 1.7 & 2.0 & 0.3 \\
\hline China & 1.0 & 1.6 & 0.6 \\
\hline India & 1.9 & 2.1 & 0.2 \\
\hline Other Low-Income & 2.9 & 3.0 & 0.1 \\
\hline Lower Middle-Income Developing & 2.4 & 2.6 & 0.2 \\
\hline Upper Middle-Income Developing & 2.1 & 2.5 & 0.4 \\
\hline Industrial Market & 0.4 & 0.6 & 0.2 \\
\hline
\end{tabular}

Source: Wor ld Bank, World Development Report 1984. 
Appendix Table A.I

Developing Countries by Income Group and Geographic Region

Region

Africa south

of Sahara

Middle East

and North Africa
Income Group

\begin{tabular}{|c|c|c|}
\hline $\begin{array}{l}\text { Low-Income } \\
\text { Developing } \\
\text { Countries }\end{array}$ & $\begin{array}{l}\text { Lower Middle- } \\
\text { Income Developing } \\
\text { Countries }\end{array}$ & $\begin{array}{l}\text { Upper Middle- } \\
\text { Income Developing } \\
\text { Countries }\end{array}$ \\
\hline
\end{tabular}

$\begin{array}{ll}\text { Benin } & \text { Angola } \\ \text { Burundi } & \text { Cameroon } \\ \text { Cent. African Rep. } & \text { Congo People's Rep. } \\ \text { Chad } & \text { Ivory Coast } \\ \text { Ethiopia } & \text { Lesotho } \\ \text { Ghana } & \text { Liberia } \\ \text { Guinea } & \text { Mauritania } \\ \text { Kenya } & \text { Nigeria } \\ \text { Madagascar } & \text { Senegal } \\ \text { Malawi } & \text { Sudan } \\ \text { Mali } & \text { Zambia } \\ \text { Mozambique } & \text { Zimbabwe } \\ \text { Niger } & \\ \text { Rwanda } & \\ \text { Sierra Leone } & \\ \text { Somalia } & \\ \text { Tanzania } & \\ \text { Togo } & \\ \text { Uganda } & \\ \text { Upper Volta } & \\ \text { Zaire } & \end{array}$

East Asia and Pacific
China

Kampuchea, Dem.

Lao, PDR

Viet Nam
Indonesia

Korea, N.

Mongolia

Papua New Guinea

Philippines

Tha i land
Algeria

Iran

Iraq

Jordan

Syria
Hong Kong Korea, S. Malaysia Singapore 
Appendix Table A.1 (continued)

Income Group

\begin{tabular}{|c|c|c|}
\hline $\begin{array}{l}\text { Low-Income } \\
\text { Deve loping } \\
\text { Countries }\end{array}$ & $\begin{array}{c}\text { Lower Middle- } \\
\text { Income Developing } \\
\text { Countries }\end{array}$ & $\begin{array}{c}\text { Upper Middle- } \\
\text { Income Deve loping } \\
\text { Countries }\end{array}$ \\
\hline
\end{tabular}

South Asia

Afghanistan

Bangladesh

Bhutan

Burma

India

Nepa 1

Pakistan

Sri Lanka

Lat in America

and Caribbean

$\begin{array}{ll}\text { Haiti Bolivia } & \text { Colombia } \\ \text { Costa Rica } \\ \text { Cuba } \\ \text { Dominican Rep. } \\ \text { Ecuador } \\ \text { El Salvador } \\ \text { Guatemala } \\ \text { Honduras } \\ \text { Jamaica } \\ \text { Nicaragua } \\ \text { Paraguay } \\ \text { Peru }\end{array}$

Argentina

Brazil

Chile

Mexico

Panama

Trinidad \& Tobago

Uruguay

Venezuela

South Europe

Turkey

Greece

Israe I

Portugal

Yugos lavia

Note: The countries listed in this table reflect the income group and geographic location classification used by the World Bank in its 1984 World Development Report. All of the countries in this table had mid-1982 populations exceeding one million persons. 


\title{
Appendix Table A.2 \\ Industrial Market Economies
}

\author{
Australia \\ Austria \\ Belgium \\ Canada \\ Denmark \\ Finland \\ France \\ Germany, Fed. Rep. \\ Ireland \\ Italy \\ Japan \\ Nether lands \\ New Zea land \\ Norway \\ Spain \\ Sweden \\ Switzer land \\ United Kingdom \\ United States
}

Note: The countries listed in this table reflect the income group classification used by the World Bank in its 1984 World Development Report. All of the countries in this table had mid-1982 populations exceeding one million persons. 